\title{
Larviculture of two neotropical species with different distributions in the water column in light- and dark-colored tanks
}

\author{
Marcelo Mattos Pedreira ${ }^{1}$, Edson Vieira Sampaio ${ }^{2}$, \\ José Cláudio Epaminondas dos Santos ${ }^{2}$ and Aldrin Vieira Pires ${ }^{1}$
}

The influence of tank color on the visual perception of fish larvae and the success of their cultivation depends on the characteristics of each species combined with environmental factors. In this study, we determined the effect of light and dark tank colors on the larviculture of pacamã (Lophiosilurus alexandri), a species with a benthonic habit, and curimatá-pioa (Prochilodus costatus), which swims actively in the water column. Larvae of pacamã and curimatá-pioa were cultivated for 10 days in 5-L tanks, at a density of 15 larvae $\mathrm{L}^{-1}$ and luminosity of $141.7 \pm 8.95$ lux, and fed Artemia nauplii. Four tank colors were used: green, light blue, brown, and black (with four replications). Survival, biomass and Fulton's condition factor for pacamã larvae were similar in the different colored tanks. However, the larvae in the green tanks showed lower weight than those cultivated in black and brown tanks, as well as shorter total length than that of larvae in the brown-colored tanks. These results are probably due to the association between tank color and benthonic habitat of the pacamã. For the curimatá-pioa, survival and biomass were similar for the different colors. The weight and Fulton's condition factor were higher for the larvae cultivated in green and blue tanks. This result could be associated with the adaptation of curimatá-pioa larvae to active swimming in the water column, searching for prey.

A interferência da cor do tanque na percepção visual da larva de peixe e no sucesso do seu cultivo depende da caraterística de cada espécie combinada com fatores ambientais. Neste estudo foi investigado o efeito de tanques de cores claras e escuras na larvicultura do pacamã Lophiosilurus alexandri, espécie de hábito bentônico, e, curimatá-pioa Prochilodus costatus, que nada ativamente na coluna da água. Larvas de pacamã e de curimatá-pioa foram cultivadas por 10 dias, em tanques contendo $5 \mathrm{~L}$ de água, a uma densidade de 15 larvas L ${ }^{-1}$, luminosidade de $141.7 \pm 8.95$ lux, alimentados com náuplios de Artemia. Quatro cores de tanques foram usadas: verde e azul claras, marrom e preta (com quatro repetições). Para as larvas de pacamã, a sobrevivência, biomassa e o fator de condição de Fulton foram similares entre os tanques de diferentes cores. Entretanto, as larvas nos tanques verdes apresentara um peso menor do que as cultivadas nos tanques de cor preta e marrom, assim como um menor comprimento total, que as larvas cultivadas em tanque marrom. Estes resultados provavelmente têm origem da associação da cor do tanque com o hábito bentônico do pacamã. Para o curimatá-pioa, a sobrevivência e a biomassa foram similares entre as cores. O peso e o fator de condição de Fulton foram maiores para as larvas cultivadas nos tanques de cor verde e azul, seguidas pelo marrom e preto. Este resultado pode estar associado a adaptação das larvas de curimatá-pioa a natação ativa na coluna da água à procura de presa.

Key words: Endemic, Lophiosilurus alexandri, Prochilodus costatus, rio São Francisco, Visual perception.

\section{Introduction}

The pacamã, Lophiosilurus alexandri Steindachner, 1876, and the curimatá-pioa, Prochilodus costatus Valenciennes, 1850, are species native to the São Francisco basin and are prominent in regional fishing (Barbosa \& Soares, 2009), stimulating an interest in their aquaculture. However, each has a different biology. Pacamã is a piscivorous species (Alvim \& Peret, 2004) that is distributed on the bottom, with the adults building nests in sandy ponds where they spawn (Travassos, 1959). The curimatá-pioa are detritivorous (Luz et al., 2009) and active swimmers, migrating upriver to reproduce (Silva et al., 2006; Alves, 2007), and their larvae swim in all directions and levels of the water column, from the fourth post-hatching day (Godinho et al., 2003).

${ }^{1}$ Universidade Federal dos Vales do Jequitinhonha e Mucuri, Laboratório de Aquicultura e Ecologia Aquática, Alto da Jacuba, 39100-000 Diamantina, Minas Gerais, Brazil. marcelo_ufvjm@hotmail.com (MMP)

${ }^{2}$ Companhia de Desenvolvimento dos Vales do São Francisco e do Parnaíba, Estação de Hidrobiologia e Piscicultura de Três Marias. 
Vision seems to be the dominant sense in feeding for fish larvae (Arthur, 1976), but beyond their visual capacity, catfish larvae can chemically locate their food through their barbels (Brito \& Pienaar, 1992; Weingartner \& Zaniboni-Filho, 2004), showing better performance under low luminosity (Behr et al., 1999; Feiden et al., 2005).

Many species of larvae hatch with eyes regarded as nonfunctional until the start of exogenous feeding (Blaxter \& Hunter, 1982), a condition that emerges with the development of the organism. Pacamã larvae hatch with their eyes slightly pigmented (Nakatani et al., 2001), while larvae of curimatápioa begin to develop eye pigment on the third day, when they begin to open their mouth (Godinho et al., 2003).

The aim of this work was to study the effect of light and dark colors on the survival and growth of larvae of pacamã, a species with benthic habits, and curimatá-pioa, which swims actively in the water column.

\section{Material and Methods}

The experiments were conducted at the Centro Integrado de Recursos Pesqueiros e Aquicultura de Três Marias da Companhia de Desenvolvimento do Vale do São Francisco e do Parnaíba - CODEVASF, in Três Marias - MG, Brazil. Larvae of pacamã (Lophiosilurus alexandri) and curimatápioa (Prochilodus costatus) were obtained from the same breeder and cultivated for 10 days. Pacamã larvae had a total length of $13.3 \pm 0.5 \mathrm{~mm}$ and weight of $15.5 \pm 3.3 \mathrm{mg}$, and curimatá-pioa had a total length of $6.9 \pm 0.4 \mathrm{~mm}$ and weight of $1.7 \pm 0.8 \mathrm{mg}$.

The larvae were counted individually and distributed in 7-L tanks, with $5 \mathrm{~L}$ of water, at a density of 15 larvae $\mathrm{L}^{-1}(75$ larvae $\left.\operatorname{tank}^{-1}\right)$. The tanks were continuously aerated and luminosity was $141.7 \pm 8.95$ lux on the water surface, obtained from two 40-W fluorescence lamps set at a height of $2.5 \mathrm{~m}$. The photoperiod was 12L:12D.

The larvae species were submitted to four tank colors: two light colors (green and blue) and two dark colors (brown and black), with four replications each, in a completely randomized design.

A Minolta CR 400 colorimeter was used to measure color and lightness of the tanks (Table 1). The colors were expressed in CIELab coordinates. In this system, $\mathrm{L}^{*}$ represents the lightness of color points on a 0-100 scale from black to white, $a^{*}$ is the position between red $(+)$ and green $(-)$, while $b^{*}$ is the position between yellow $(+)$ and blue (-), and thus, $a^{*}$ and $\mathrm{b}^{*}$ are chromaticity coordinates. Color intensity is expressed by a Chroma $\mathrm{C}^{*}$ ab value, which is the purest and most intense color, and is influenced by coordinates $\mathrm{a}^{*}$ and $\mathrm{b}^{*}$, and $\mathrm{H}_{\mathrm{ab}}^{\circ}$ corresponds to the hue. These values were calculated according to the formulas:

$\mathrm{C}^{*}{ }_{\mathrm{ab}}=\left(\mathrm{a}^{* 2}+\mathrm{b}^{* 2}\right)^{1 / 2}$
$\mathrm{H}^{\mathrm{o}}=\arctan \left(\mathrm{b}^{*} / \mathrm{a}^{*}\right)$

Water temperature, dissolved oxygen (YSI 55), redox potential, $\mathrm{pH}$ (Quimis Q400H) and electrical conductivity (Lutron 4301) were measured daily at 7 am in each tank. After the reading of water parameters, waste was removed, and $10 \%$ of the water volume was exchanged.

The fish larvae were fed 600 Artemia nauplii pacamã larva $^{-1}$ and 400 Artemia nauplii curimatá-pioa larva ${ }^{-1}$, offered twice a day ( 8 am and $2 \mathrm{pm})$. On the sixth day, there was a $50 \%$ increase in the amount of offered prey per larva; this amount was maintained until the end of the experiment.

The Artemia nauplii were obtained from cysts maintained for $24 \mathrm{~h}$ in salinity of $28.5 \%$. The nauplii were counted under a stereoscopic microscope for the verification of concentration (nauplii $\mathrm{mL}^{-1}$ ), and the number of larval food was determined. At the end of the experiment, all larvae were counted and their survival calculated. Their biomass was obtained by weighing all larvae in the tank, on a scale with a precision of $0.1 \mathrm{mg}$. Total length (obtained using a caliper with a precision of $0.02 \mathrm{~mm}$ ) and average weight of the larvae (obtained using a scale with a precision of $0.1 \mathrm{mg}$ ) were taken for 15 larvae tank $^{-1}$.

All larvae were captured at the same time and preserved in $10 \%$ formalin, Afterwards, the number of the prey larva $\mathrm{a}^{-1}$ was obtained by intestinal dissection of four larvae tank $\mathrm{k}^{-1}$, under a stereomicroscope. The entire gut was removed intact from each specimen and placed in a drop of water on a glass slide. The digestive tracts of the larvae were opened lengthwise with a needle, and the items in the gut of each larva were counted (Arthur, 1976). The stage of digestion of the prey was high (ranking based on Daan, 1973 and Scrimgeour \& Winterbourn, 1987).

During the experiment, it was observed if larvae swam continuously or not, dispersed or grouped, or showed aggressive behavior (agonistic patterns, damaged fins, or other signs of attack).

Using the total weight and standard length data obtained at the end of the experiment, Fulton's condition factor was calculated by the expression: $\mathrm{K}=$ (weight/ standard length ${ }^{-3}$ ) $\mathrm{1} 100$.

Table 1. Averages ( \pm standard deviation) of $\mathrm{L}^{*}$ (lightness), $\mathrm{C}_{\mathrm{ab}}^{*}\left(\right.$ Chroma $=$ color intensity) and $\mathrm{H}_{\mathrm{ab}}^{\circ}$ (hue) of the tanks employed in the cultivation of the larvae of curimatá-pioa (Prochilodus costatus) and pacamã (Lophiosilurus alexandri), for 10 days. Averages in the same column followed by different letters differed significantly $(\mathrm{P}<0.05)$ by Tukey's test.

\begin{tabular}{|c|c|c|c|c|c|}
\hline Color & $a^{*}$ & $b^{*}$ & $\mathrm{~L}^{*}$ & $\mathrm{C}_{\mathrm{ab}}$ & $\mathrm{H}_{\mathrm{ab}}^{\mathrm{o}}$ \\
\hline Green & $-25.92 \pm 0.24^{\mathrm{d}}$ & $43.32 \pm 0.51^{\mathrm{a}}$ & $66.49 \pm 0.29^{b}$ & $50.48 \pm 0.53^{\mathrm{a}}$ & $65.45^{\mathrm{a}}$ \\
\hline Blue & $-14.33 \pm 0.13^{c}$ & $-31.99 \pm 0.51^{\mathrm{d}}$ & $53.61 \pm 0.48^{c}$ & $34.51 \pm 0.51^{\mathrm{bc}}$ & $-59.10^{\mathrm{e}}$ \\
\hline Brown & $24.60 \pm 2.03^{\mathrm{a}}$ & $25.19 \pm 1.82^{\mathrm{b}}$ & $43.21 \pm 0.39^{\mathrm{d}}$ & $35.21 \pm 2.73^{\mathrm{b}}$ & $45.68^{b}$ \\
\hline Black & $0.08 \pm 0.02^{b}$ & $-0.03 \pm 0.04^{c}$ & $25.43 \pm 1.46^{\mathrm{e}}$ & $0.09 \pm 0.03^{\mathrm{c}}$ & $-10.48^{c}$ \\
\hline
\end{tabular}


The survival percentage values were arcsine transformed for statistical analysis. The evaluations of the effect of tank color and water quality were compared to the average values of the larvae by the F test, followed by Tukey's test at $5 \%$ significance, using SigmaStat 3.5 software.

\section{Results and Discussion}

Water quality parameters (Table 2) were similar to those observed by other authors for the culture of larvae of pacamã (Pedreira et al., 2008a; Pedreira et al., 2009) and curimatápioa (Luz et al., 2009), and were similar between treatments, not interfering with the observed differences. The luminosity $\left(\mathrm{L}^{*}\right)$ differed between tanks with different colors, which influenced the development and survival of pacamã and curimatá-pioa larvae alike.

The pacamã larvae were constantly on the bottom, forming clusters and searching for points with low luminosity. In the green tank they showed smaller weight and length, under the higher reflected light. However, survival, biomass, Fulton's condition factor (Table 3) and consumption of prey (Table 4) did not differ.

The curimatá-pioa larvae swam actively in the water column and showed the lowest consumption of prey in the black tanks and better results for weight, length and Fulton's condition factor in the light-colored tanks (blue and green), but biomass and survival did not differ between treatments (Table 3 ).

The distribution of pacamã larvae on the bottom in this experiment was the same behavior observed for pacamã in the adult phase (Travassos, 1959). It explains the lower weight and length yield in the green tank with better reflection of light. Tenório et al. (2006) observed better pacamã growth when they were submitted to 24 hours of darkness than when submitted to 24 hours of light. These results are in agreement with the idea that pacamã larvae are adapted to darker environments, as evidenced by the present work when they crowded around points with low luminosity.
Continuous darkness enhances the growth of Clarias gariepinus larvae, another siluriform with similar behavior as pacamã, during and after metamorphosis (Appelbaum \& McGeer, 1998). The growth rate of larval C. gariepinus was found to increase with shorter light periods, the highest being recorded in continuous darkness (0L:24D photoperiod). The behavior of larval and juvenile catfish differs markedly in continuous light and darkness. When subjected to a continuous light period, a strong negative phototaxis, long rest periods interspersed with disturbed activity, refugeseeking behavior and increased incidence of territorial aggression were observed (Brito \& Pienaar, 1992). However, it should be noted that in the present work, the pacamã larvae did not show signs of aggressiveness.

For curimatá-pioa, the best results were obtained in the light-colored tanks (blue and green), whereas less consumption of prey occurred in the black tanks. These results suggest that the larvae are adapted to more intense luminosity, normally found in the water column, where they swim actively starting on the fourth day of life (Godinho et al., 2003) and retain this behavior during the adult phase when they migrate for reproduction (Silva et al., 2006; Alves, 2007).

Receptivity of fish to light profoundly changes according to species and developmental status (Boeuf \& Pierre-Yves, 1999). Also, increasing or decreasing light intensity interferes with the visual detection of larvae by the prey as well (Tamazouzt et al., 2000). In the natural habitat, pacamã larvae are distributed on the bottom and are submitted to lower luminosity than curimatá-pioa larvae, which are distributed throughout the water column. This difference in behavior is related to light intensity for these species, since pacamã are better adapted than curimatá-pioa to places with lower luminosity. The ability and position of the eyes in fish larvae are likely due to an adaptation to the habitat. Usually, the larvae of species that live on the bottom have their eyes turned upward - including sole after its transformation to benthic (Osse \& Van den Boogaartt, 1997; Sæle et al., 2003; Pedro-

Table 2. Average values ( \pm standard deviation) of water quality parameters of cultivation of the larvae of pacamã (Lophiosilurus alexandri) and curimatá-pioa (Prochilodus costatus) in tanks of four different colors, for 10 days. Averages in the same row did not differ $(\mathrm{P}>0.05)$ significantly by Tukey's test.

\begin{tabular}{|c|c|c|c|c|}
\hline \multicolumn{5}{|c|}{ Lophiosilurus alexandri } \\
\hline Color of tank & Green & Blue & Brown & Black \\
\hline Temperature $\left({ }^{\circ} \mathrm{C}\right)$ & $26.7 \pm 0.6$ & $26.7 \pm 0.5$ & $26.6 \pm 0.5$ & $26.6 \pm 0.5$ \\
\hline Redox (mV) & $75.6 \pm 61.1$ & $72.5 \pm 58.4$ & $72.5 \pm 63.8$ & $72.4 \pm 60.4$ \\
\hline $\mathrm{pH}$ & $7.8 \pm 0.14$ & $7.7 \pm 0.08$ & $7.8 \pm 0.15$ & $7.8 \pm 0.18$ \\
\hline Conductivity $\left(\mathrm{mS} \mathrm{cm}^{-1}\right)$ & $739 \pm 556$ & $699 \pm 509$ & $711 \pm 522$ & $842 \pm 656$ \\
\hline Oxygen $\left(\mathrm{mg} \mathrm{L}^{-1}\right)$ & $5.3 \pm 0.6$ & $5.3 \pm 0.5$ & $5.7 \pm 0.7$ & $5.3 \pm 0.5$ \\
\hline Oxygen (\%) & $66.5 \pm 7.5$ & $66.7 \pm 6.8$ & $67.3 \pm 5.9$ & $66.4 \pm 6.0$ \\
\hline \multicolumn{5}{|c|}{ Prochilodus costatus } \\
\hline Color of tank & Green & Blue & Brown & Black \\
\hline Temperature $\left({ }^{\circ} \mathrm{C}\right)$ & $26.7 \pm 0.5$ & $26.7 \pm 0.5$ & $26.6 \pm 0.5$ & $26.6 \pm 0.5$ \\
\hline Redox (mV) & $59 \pm 78$ & $57 \pm 83$ & $57 \pm 82$ & $58 \pm 85$ \\
\hline $\mathrm{pH}$ & $7.7 \pm 0.1$ & $7.8 \pm 0.1$ & $7.8 \pm 0.1$ & $7.8 \pm 0.2$ \\
\hline Conductivity $\left(\mathrm{mS} \mathrm{cm}^{-1}\right)$ & $601 \pm 392$ & $581 \pm 379$ & $618 \pm 397$ & $678 \pm 459$ \\
\hline Oxygen $\left(\mathrm{mg} \mathrm{L}^{-1}\right)$ & $5.0 \pm 0.8$ & $5.1 \pm 0.8$ & $5.2 \pm 0.6$ & $5.3 \pm 0.4$ \\
\hline Oxygen $(\%)$ & $64.6 \pm 12.5$ & $64.2 \pm 9.5$ & $64.9 \pm 8.2$ & $66.3 \pm 4.4$ \\
\hline
\end{tabular}


Table 3. Average values ( \pm standard deviation) of the larvae of pacamã (Lophiosilurus alexandri) and curimatá-pioa (Prochilodus costatus) cultivated in tanks of four different colors, for 10 days. $\mathrm{K}=$ Fulton's condition factor. Averages in the same column followed by different letters differed significantly $(\mathrm{P}<0.05)$ by Tukey's test.

\begin{tabular}{|c|c|c|c|c|c|}
\hline \multicolumn{6}{|c|}{ Lophiosilurus alexandri } \\
\hline Color of tank & Survival (\%) & Length (mm) & Weight (mg) & Biomass (g) & $\mathrm{K}$ \\
\hline Green & $97 \pm 0.8^{\mathrm{a}}$ & $16.7 \pm 0.9^{b}$ & $27.6 \pm 3.1^{b}$ & $2.21 \pm 0.2^{\mathrm{a}}$ & $5.8 \pm 1.0^{\mathrm{a}}$ \\
\hline Blue & $96 \pm 1.9^{\mathrm{a}}$ & $17.2 \pm 1.6^{\mathrm{ab}}$ & $30.1 \pm 3.0^{\mathrm{ab}}$ & $2.13 \pm 1.7^{\mathrm{a}}$ & $5.9 \pm 1.1^{\mathrm{a}}$ \\
\hline Brown & $94 \pm 10.7^{\mathrm{a}}$ & $17.7 \pm 0.7^{\mathrm{a}}$ & $30.9 \pm 5.2^{\mathrm{a}}$ & $2.18 \pm 0.3^{\mathrm{a}}$ & $5.6 \pm 1.0^{\mathrm{a}}$ \\
\hline Black & $97 \pm 5.8^{\mathrm{a}}$ & $17.2 \pm 0.6^{\mathrm{ab}}$ & $31.0 \pm 4.9^{\mathrm{a}}$ & $2.12 \pm 1.1^{\mathrm{a}}$ & $6.6 \pm 1.6^{\mathrm{a}}$ \\
\hline \multicolumn{6}{|c|}{ Prochilodus costatus } \\
\hline Color of tank & Survival (\%) & Length (mm) & Weight (mg) & Biomass (g) & $\mathrm{K}^{1}$ \\
\hline Green & $74.3 \pm 12.5^{\mathrm{a}}$ & $9.2 \pm 0.09^{\mathrm{a}}$ & $5.0 \pm 1.3^{\mathrm{a}}$ & $0.024 \pm 0.004^{\mathrm{a}}$ & $6.3 \pm 1.5^{\mathrm{a}}$ \\
\hline Blue & $92.4 \pm 7.3^{\mathrm{a}}$ & $8.9 \pm 0.04^{b}$ & $4.7 \pm 1.0^{\mathrm{a}}$ & $0.025 \pm 0.003^{\mathrm{a}}$ & $6.6 \pm 1.6^{\mathrm{a}}$ \\
\hline Brown & $89.0 \pm 7.9^{\mathrm{a}}$ & $8.5 \pm 0.04^{\mathrm{c}}$ & $3.5 \pm 0.9^{\mathrm{b}}$ & $0.022 \pm 0.004^{\mathrm{a}}$ & $5.6 \pm 1.1^{b}$ \\
\hline Black & $96.2 \pm 5.4^{\mathrm{a}}$ & $8.6 \pm 0.05^{\mathrm{c}}$ & $3.6 \pm 0.9^{\mathrm{b}}$ & $0.023 \pm 0.004^{\mathrm{a}}$ & $5.5 \pm 0.8^{b}$ \\
\hline
\end{tabular}

Cañavate et al., 2006) and some Siluriformes (Oliveira et al., 2008), such as pacamã. On the other hand, pelagic species have eyes placed laterally (Kirchheim \& Goulart, 2010).

The contrast between the color of the food organism and the wall of the tank is important for the visual perception of the prey by the larvae (Krise \& Meade, 1986; Ostrowsky, 1989), providing higher or lower visibility and consumption of prey (Pedreira \& Sipaúba-Tavares, 2001; Strand et al., 2007), and also affecting survival (Tamazouzt et al., 2000; Pedreira et al., 2008b), growth (Jentoft et al., 2006; Strand et al., 2007; Monk et al., 2008), biochemical parameters (Karakatsouli et al., 2007), skin pigmentation (Amiya et al., 2005; Doolan et al., 2007), agonistic behavior and motor activity (Merighe et al., 2004), and finally productivity (Pedreira \& Sipaúba-Tavares, 2001).

Tanks with green, blue and brown colors resulted in a higher number of prey curimbatá-pioa larva ${ }^{-1}$ than the black tank. However, these relationships are not always simple. Larvae of pacamã ate the same amount of prey when subjected to aquaria of different colors and showed differences in growth between those cultivated in green and black tanks. Pedreira et al. (2008a) observed differences in the survival rate and growth of pacamã fed the same number of prey. Luz \& Zaniboni-Filho (2001), while subjecting fish larvae to different concentrations of food plankton, did not find a significant difference in survival and growth of larvae. Tests with tank color and luminosity have shown differences with regard to the characteristics of the larvae, which can change during the development of the organism.

Pedro-Canãvate et al. (2006) observed that the intake rate of sole (Solea senegalensis) larvae increased during

Table 4. Average values ( \pm standard deviation) of number of prey larva ${ }^{-1}$ for curimatá-pioa (Prochilodus costatus) and pacamã (Lophiosilurus alexandri) cultivated in tanks of four different colors, after 10 days. Averages in the same column followed by different letters differed significantly $(\mathrm{P}<0.05)$ by Tukey's test.

\begin{tabular}{lcc}
\hline Color of tank & P. costatus & L. alexandri \\
\hline Green & $11.2 \pm 5.9^{\mathrm{a}}$ & $5.9 \pm 7.9^{\mathrm{a}}$ \\
Blue & $12.8 \pm 5.4^{\mathrm{a}}$ & $12.3 \pm 13.1^{\mathrm{a}}$ \\
Brown & $8.4 \pm 5.6^{\mathrm{a}}$ & $7.4 \pm 6.1^{\mathrm{a}}$ \\
Black & $0.2 \pm 0.4^{\mathrm{b}}$ & $14.1 \pm 15.4^{\mathrm{a}}$ \\
\hline
\end{tabular}

development. Despite the fact that larval S. senegalensis is a visual predator during the first days of life, the pelagic phase, it starts to transform to benthonic on the eighth day, and begins to capture prey in the dark. Some catfish larvae live on the bottom in cloudy water; in the case of the pacamã, in addition to its vision, they have barbels that serve to perceive prey and the environment.

Weingartner \& Zaniboni-Filho (2004) observed that the catfish "mandi amarelo" (Pimelodus maculatus) detects food not only through vision but can locate food chemically through their barbels. According to Nakatani et al. (2001), these structures are present before the opening of the mouth in the pacamã. The authors observed that the larvae of "mandi amarelo" featured a longer length when submitted to black color tanks, despite the similarities in survival and weight. Feiden et al. (2005) suggested the rearing of larval "surubim do Iguaçu" (Steindachneridion sp.) in the absence of light can lead to reduced aggressiveness, and consequently less cannibalism, allowing better development, which resulted in $63.3 \%$ survival when fed zooplankton and $85.0 \%$ when fed Artemia. The authors compared the weight found in the literature for the same species and similar experimental conditions, and observed the importance of the absence of light on the development of "surubim do Iguaçu." The South American catfish (Rhamdia quelen), whose larvae are cannibalistic, displays greater growth in weight and length when reared in a dark environment (1.2 lux) (Behr et al., 1999). Clarias gariepinus larvae are nocturnally active, tactile feeders, with a distinct feeding activity pattern. The refuge-seeking behavior observed in the light is interpreted as an adaptation to avoid predators that rely on sight to detect prey (Brito \& Pienaar, 1992).

However, Fulton's condition factor, an indicator of the degree of fish welfare (Rossi et al., 2007), was equal among the larvae of pacamã submitted to the different colors. Similar responses were observed by Papoutsoglou et al. (2000) for common carp (Cyprimus carpio) juveniles reared in white, black and green tanks. However, the results differ for species that swim actively in the water column in search for food, such as the larvae of curimatá-pioa. Pedreira \& SipaúbaTavares (2001), working with larvae of "tambaqui" (Colossoma macropomum), observed that the light-colored tanks provided more visual contrast with the prey, increasing 
their capture efficiency by the larvae, and consequently resulting in a better yield. According to these authors, the higher survival rate occurred due to the better contrast between the tank color and the strong coloration of tropical freshwater plankton.

Pedreira et al. (2008b) recommended the larviculture of "matrinxã do São Francisco" (Brycon orthotaenia) in lightcolored tanks (white, light blue and light green), which provided better survival and growth. Tamazouzt et al. (2000) observed that perch (Perca fluviatilis) reared in white and gray tanks, ingested more food items than in black tanks, with the growth rate being higher in white tanks than in black ones. They found that the food level of the remaining perch larvae increased in black tanks compared to the white tank under lower luminosity conditions. Under higher light intensity, the high ingestion rates resulted from the increased visibility of the food, probably due to the higher contrast between the prey and tank color. The authors concluded that the interaction between color and light intensity is an important factor to be considered for performance optimization in perch larviculture.

The larvae of curimatá-pioa (Prochilodus costatus) showed a higher Fulton's condition factor when submitted to green and blue tanks, indicating that the light-colored tanks should be employed in the larviculture of this species. A similar result was observed by Pedreira et al. (2008b) working with larvae of Brycon orthotaenia reared in light-colored tanks (white, light blue and light green). This is a species from the same basin as curimatá-pioa, and it is a neotropical characiform that swims in the water column. The larvae of Perca fluviatilis reared in black tanks showed an improved Fulton's condition factor compared to the gray tanks (Jentoft et al., 2006), suggesting the response can vary for some species.

In addition to the contrast between prey and their environment, tank color can affect the welfare of larvae. For perch larvae, tank color and light intensity influences behavioral and physiological stress, which can result in reduced growth rate and feeding (Strand et al., 2007). Common carp larvae reared in white tanks showed higher specific growth and lower food conversion rates and plasma cortisol levels than those kept in black and green tanks, suggesting lower stress in white tanks (Papoutsoglou et al., 2000). It is possible that better results with pacamã larvae in brown tanks, followed by black, blue and green, are also associated with animal welfare. This may be one of the research lines to follow, as suggested by Peña et al. (2004), who reported on the perception capacity of fish larvae and their development of physiological responses. Volpato \& Barreto (2001) observed that rearing in green and white light increased cortisol levels in Nile tilapia (Oreochromis mossambicus) adults, but there was no effect when these fish were maintained under blue light. According to the author, the study showed that blue light prevents an increase in cortisolinduced stress in Nile tilapia.

We conclude that the brown and black dark-colored tanks are more suitable for rearing pacamã larvae compared to light green- and blue-colored tanks. This seems to be associated with their distribution on the bottom in the natural environment, where the light is less intense. However, for curimatá-pioa larvae, which swim actively in the water column searching for prey, light green and blue tanks are more suitable for rearing, in which they seem to see their prey better, resulting in better growth.

\section{Acknowledgements}

This research received financial support from FAPEMIG (Fundação de Amparo à Pesquisa do Estado de Minas Gerais, Brazil), CNPq (Conselho Nacional de Desenvolvimento Científico e Tecnológico, Brazil), BNB (Banco do Nordeste do Brasil) and CEMIG (Companhia de Energética de Minas Gerais, Brazil)/CODEVASF (Companhia de Desenvolvimento dos vales do São Francisco e Parnaíba, Brazil). We thank Yoshimi Sato and Léa Sá Fortes Pedreira for suggestions and ideas for this paper.

\section{Literature Cited}

Alves, C. B. M. 2007. Evaluation of fish passage through the Igarapé Dam fish ladder (rio Paraopeba, Brazil), using marking and recapture. Neotropical Ichthyology, 5: 233-236.

Alvim, M. C. C. \& A. C. Peret. 2004. Food resources sustaining the fish fauna in a section of the upper São Francisco river in Três Marias, MG, Brazil. Brazilian Journal of Biology, 64: 195-202.

Amiya, N., M. Amano, A. Takahashi, T. Yamanome, H. Kawauchi \& K. Yamamori. 2005. Effects of tank color on melaninconcentrating hormone levels in the brain, pituitary gland, and plasma of the barin flounder as revealed by a newly developed time-resolved fluorimmunoassay. General and Comparative Endocrinology, 143: 251-256.

Appelbaum, S. \& J. C. McGeer. 1998. Effect of diet and light regime on growth and survival of African catfish (Clarias gariepinus) larvae and early juveniles. Aquaculture Nutrition, 4: 157-164.

Arthur, D. K. 1976. Food and feeding of larvae of three fishes occurring in the California Current, Sardinops sagax, Engraulis mordax, and Trachurus symmetricus. Fishery Bulletin, 74: 517-530.

Barbosa, J. M. \& E. C. Soares. 2009. Perfil da ictiofauna da bacia do São Francisco: estudo preliminar. Revista Brasileira de Engenharia de Pesca, 4: 155-172.

Behr, E. R., J. Radünz-Neto, A. P. Tronco \& A. P. Fontana. 1999. Efeitos de diferentes níveis de luminosidade sobre o desempenho de larvas de jundiá (Rhamdia quelen) (Quoy \& Gaimard, 1824) (Pisces: Pimelodidae). Acta Scientiarum, 21: 325-330.

Blaxter, J. H. S. \& J. R. Hunter. 1982. The biology of the clupeoid fishes. Advances in Marine Biology, 20: 1-224.

Boeuf, G. \& Le B. Pierre-Yves. 1999. Does light have an influence on fish growth? Aquaculture, 177: 129-152.

Brito, P. J. \& A. G. Pienaar. 1992. Laboratory experiments on the effect of light and cover on the behaviour and growth of African catfish, Clarias gariepinus (Pisces: Clariidae). Journal of Zoology, 227: 43-62.

Daan, N. 1973. A quantitative analysis of the food intake of North Sea cod Gadus morhua. Netherlands Journal of Sea Research, 6: 479-517.

Doolan, B. J., M. A. Booth, P. L. Jones \& G. L. Allan. 2007. Effect of cage colour and light environment on the skin colour of 
Australian snapper Pargus auratus (Bloch \& Schneider, 1801). Aquaculture Research, 38: 1395-1403.

Feiden, A., C. Hayashi, W. R. Boscolo \& A. Signor. 2005. Desenvolvimento do surubim do Iguaçu (Steindachneridion sp., Garavello (1991) (Siluroidei: Pimelodidae) em ambiente escuro durante a fase inicial, alimentado com diferentes dietas. Semina: Ciências Agrárias, 26: 109-116.

Godinho, H. P., J. E. Santos \& Y. Sato. 2003. Ontogênese larval de cinco espécies de peixes do São Francisco. Pp. 133-148. In: Godinho, H. P. \& A. L. Godinho (Orgs.). Águas, peixes e pescadores do São Francisco das Minas Gerais. PUCMinas, Belo Horizonte, 468p.

Jentoft, S., S. Øxnevad, A. H. Aasteveit \& Ø. Andersen. 2006. Effects of tank wall color and up-welling water flow on growth and survival of Eurasian Perch larvae (Perca fluviatilis). Journal of the World Aquaculture Society, 37: 313-317.

Karakatsouli, N., S. E. Papoutsoglou \& G. Manolessos. 2007. Combined effects of rearing density and tank colour on the growth and welfare of juvenile white sea bream Diplodus sargus L. in a recirculating water system. Aquaculture Research, 38: 1152-1160.

Kirchheim, P. D. \& E. Goulart. 2010. Ecomorfologia de predação e antipredação em siluriformes (Osteichthyes). Oecologia Australis, 14: 550-568.

Krise, W. F. \& J. W. Meade. 1986. Review of the intensive culture of walleye fry. The Progressive Fish-Culturist, 48: 81-89.

Luz, R. K. \& E. Zaniboni-Filho. 2001. Utilização de diferentes dietas na primeira alimentação do mandi amarelo (Pimelodus maculatus, Lacépéde). Acta Scientiarum, 23: 483-489.

Luz, S. C. S., A. C. A. el-Deir, E. J. França \& W. Severi. 2009. Estrutura da assembléia de peixes de uma lagoa marginal desconectada do rio, no submédio Rio São Francisco, Pernambuco. Biota Neotropical, 9: 117-129.

Merighe, G. K. F., E. M. Pereira-da-Silva, J. A. Negrão \& S. Ribeiro. 2004. Effect of background color on the social stress in Nile tilapia (Oreochromis niloticus). Brazilian Journal of Animal Science, 33: 828-837.

Monk, J., V. Puvanendran \& J. A. Brown. 2008. Does different tank bottom colour affect the growth, survival and foraging behaviour of Atlantic cod (Gadus morhua) larvae? Aquaculture, 277: 197-202.

Nakatani, K., A. A. Agostinho, G. Baumgartner, A. Bialetzki, P. V. Sanches, M. C. Makrakis \& C. S. Pavanelli. 2001. Ovos e larvas de água doce: desenvolvimento e manual de identificação. Eduem, Maringá. 378p.

Oliveira, E. C., A. Bialetzki \& L. F. Assakawa. 2008. Morphological development of Hypophthalmus fimbriatus and H. marginatus postyolk-sac larvae (Siluriformes: Pimelodidae). Zootaxa, 1707: 37-48.

Osse, J. W. M. \& J. G. M. Van-den-Boogaart. 1997. Size of flatfish larvae at transformation, functional demands and historical constraints. Journal of Sea Research, 37: 229-239.

Ostrowski, A. C. 1989. Effect of rearing tank background color on early survival of dolphin larvae. The Progressive Fish-Culturist, 51: 161-163.

Papoutsoglou, S. E., G. Mylonakis, H. Miliou, N. P. Arakatsouli \& S. Chadio. 2000. Effects of background color on growth performances and physiological responses of scaled carp (Cyprinus carpio L.) reared in a closed circulated system. Aquacultural Engineering, 22: 309-318.

Pedreira, M. M., J. C. E. dos-Santos, E. V. Sampaio, F. N. Pereira \& J. L. Silva. 2008a. Efeito do tamanho da presa e do acréscimo de ração na larvicultura de pacamã. Revista Brasileira de Zootecnia, 37: 1144-1150.
Pedreira, M. M., R. K. Luz, J. C. E. dos-Santos, C. C. Mattioli \& C. L. Silva. 2008b. Larvicultura de matrinxã em tanques de diferentes cores. Pesquisa Agropecuária Brasileira, 43: 1365-1369.

Pedreira, M. M., R. K. Luz, J. C. E. dos-Santos, E. V. Sampaio \& R. S. F. Silva. 2009. Biofiltração da água e tipos de substrato na larvicultura do pacamã. Pesquisa Agropecuária Brasileira, 44: 511-518.

Pedreira, M. M. \& L. H. Sipaúba-Tavares. 2001. Effect of light green and dark brown colored tanks on survival rates and development of tambaqui larvae, Colossoma macropomum (Osteichthyes, Serrasalmidae). Acta Scientiarum, 23: 521-525.

Pedro-Cañavate, J., R. Zerolo \& C. Fernández-Díaz. 2006. Feeding and development of Senegal sole (Solea senegalensis) larvae reared in different photoperiods. Aquaculture, 258: 368-377.

Peña, R., S. Dumas, R. Saldivar-Lucio, G. García, A. Trasviña \& D. Hernández-Ceballos. 2004. The effect of light intensity on first feeding of the spotted sand bass Paralabrax maculatofasciatus (Steindachner) larvae. Aquaculture Research, 35: 345-349.

Rossi, R. M., T. A. Guedes, V. Janeiro \& E. N. Martins. 2007. Estimação do fator de condição de peixes da espécie Tracydoras paraguayensis: uma perspectiva bayesiana. Acta Scientiarum, 29: $85-92$

Scrimgeour, G. T. \& M. J. Winterbourn. 1987. Diet, food resource partitioning and feeding periodicity of two riffle-dwelling fish species in a New Zealand river. Journal of Fish Biology, 31, 309-324.

Sæle, Ø., J. S. Solbakken, K. Watanabe, K. Hamre \& K. Pittman. 2003. The effect of diet on ossification and eye migration in Atlantic halibut larvae (Hippoglossus hippoglossus L.). Aquaculture, 220: 683-696.

Silva, A. R. M., G. B. Santos \& T. Ratton. 2006. Fish community structure of Juramento reservoir, São Francisco River basin, Minas Gerais, Brazil. Revista Brasileira de Zoologia, 23: 832840.

Strand, A., A. Alnärä, F. Staffan \& C. Magnhaen. 2007. Effects of tank colour and light intensity on feed intake, growth rate and energy expenditure of juvenile Eurasian perch, Perca fluviatilis L. Aquaculture, 272: 312-318.

Tamazouzt, L., B. Chatain \& P. Fontataine. 2000. Tank wall colour and light level affect growth and survival of Eurasian perch larvae (Perca fluviatilis). Aquaculture, 182: 85-90.

Tenório, R. A., A. J. G. Santos, J. P. Lopes \& E. M. S. Nogueira. 2006. Crescimento do niquim (Lophiosilurus alexandri Steindachner 1876), em diferentes condições de luminosidade e tipos de alimento. Acta Scientiarum, 28: 305-309.

Travassos, H. 1959. Nótula sobre o pacamã, Lophiosilurus alexandri Steindachner, 1876. Atas da Sociedade de Biologia do Rio de Janeiro, 4: 1-2.

Volpato, G. L. \& R. E. Barreto. 2001. Environmental blue light prevents stress in the fish Nile tilapia. Brazilian Journal of Medical and Biological Research, 34: 1041-1045.

Weingartner, M. \& E. Zaniboni-Filho. 2004. Efeito de fatores abióticos na larvicultura de pintado amarelo Pimelodus maculatus (Lacépède, 1803): salinidade e cor de tanque. Acta Scientiarum, 26: 151-157.

Submitted July 15, 2010 Resubmitted September 27, 2011 Accepted April 25, 2012 Published June 29, 2012 